\title{
The Symbolic-Aesthetic Dimension of Industrial Architecture as a Method of Classification and Evaluation: the Example of Bridge Structures in the Czech Republic
}

L. Popelová

This paper deals with the symbolic-aesthetic dimension of industrial and technical structures as a possible category for classifying and evaluating such structures. This category should play an important role in assessing the value of industrial and technical structures so that they are thoroughly and properly assessed as a part of our cultural heritage. This paper was presented at the XIII International TICCIH Congress in Terni in 2006.

Keywords: symbolic-aesthetic demands, industrial archeology, industrial heritage, conservation.

\section{Introduction}

This paper was prepared at the Faculty of Architecture CTU in Prague and the Research Centre for Industrial Heritage (VCPD), and was presented at the XIII International TICCIH Congress in Terni in 2006. The VCPD, which was founded in 2002, works on issues related to industrial heritage and technical monuments, and cooperates with other institutions to this end. The Centre gathers information on significant industrial heritage sites and buildings, which is compiled in a database for the use of decision-making bodies, regional planning institutions and investors and institutions in regional planning and investors.

The paper is based on texts that have been prepared under the research project Aesthetic and Symbolic Dimension of Industrial Buildings. One of the Classification Categories, which was carried out at FA CTU in Prague in 2006, and under a project funded by the Ministry of Education, Youth and Sports, Interdisciplinary Perspectives on the Development of Sectors of Technology and Industrial Architecture in the Czech Republic with a View to Typology, which was carried out at VCPD in 2006.

The paper deals with the symbolic-aesthetic dimension of industrial and technical structures as a possible category for classifying and evaluating such structures. This category should play an important role in assessing the value of such structures so that they are thoroughly and properly assessed as a part of our cultural heritage. Industrial structures from the Czech Republic are used as examples, and a specific analysis is made of two bridges.

\section{Symbolic appreciation of the world and its relationship to architecture}

First we will consider an observation made by Carl Gustav Jung about the symbolic appreciation of the world. He started that real life begins only when we are able to see the world in terms of its symbolic meaning. According to Jung, this need and capacity is a part of our natural psyche and it must receive adequate attention throughout our lives. A symbolic appreciation and interpretation of the world plays an important role not just in ordinary life, but also in connection with architecture and urban studies. The theories of C. N. Schultz, C. Jencks, K. Lynch etc., had quite different foundations, but all have pointed out that we must maintain a symbolic-aesthetic perception of our environment, at every level, from individual isolated structures to more elaborate structural complexes. Nowadays, however, we primarily approach the environment around us with practical perspectives.

Architecture and the environment come to form a meaningful unit when they, too possess this dimension. Technical and industrial structures can also be perceived as symbolic-aesthetic phenomena, which is what was intended by many of the builders and architects who conceived them. This approach to perceiving and appreciating these structures should serve as a useful argument in efforts aimed at conserving them, as many of these structures are still under threat of destruction because they are often viewed as having no significance or architectural value.

\section{The symbol and the industrial structure}

Symbolic-aesthetic values have long been a standard classification and assessment criterion for other common types of architectural works. Such values have even been overemphasised. Stereotypes have thus far dictated that this criterion is not applied to industrial or technical structures, because in their case it is assumed that functional and operational criteria take precedence over aesthetic design. Nevertheless some completed industrial and technical works are undertaken with explicitly symbolic-aesthetic ambitions. They are thus comparable with the construction of churches or representative residential buildings, and at the time of their origin they were perceived in this light. A number of important works were conceived by architects who were also engaged in theoretical work on this issue (Antonín Engel, Karel Teige, Jan E. Koula, František A. Libra, František L. Gahura, Emanuel 
Hruška). There are some industrial and technical works that are generally acknowledged as oustanding, especially works linked to the modernist movement, in which case their function was almost uncritically glorified and was imposed as the new aesthetic on most architectural work.

If we perceive and assess industrial and technical structures from an aesthetic-symbolic perspective, it is clear that the value of these works is not based only on their functional and technical components, but also derives from their specific poetry, monumentality and beauty. In contrast to other types of architecture they acquire these qualities in very interesting forms.

That it is necessary to interpret industrial structures from a symbolic-aesthetic perspective has also been pointed out by P. Neaverson and M. Palmer in their book Industrial Archeology and by other authors, such as G. Darley and B. H. Bradley.

\section{Classifying industrial and technical structures from the perspective of their symbolic-aesthetic qualities}

The categories dealt with here are close to each other, and can overlap and intermingle from time to time. The categories refer to individual objects as well as the whole setting of an plant. Individual branches of industry often incline toward certain categories, and in this area the typical features need to be described in greater detail. It will also be interesting to identify elements that are only locally typical (e.g. inspired by folk architecture) and those drawn from other cultures (e.g. the low alpine gables of the Austro-Hungarian railway stations and the use of brickwork in the Czech environment), and to think about how these categories are perceived on the subjec-

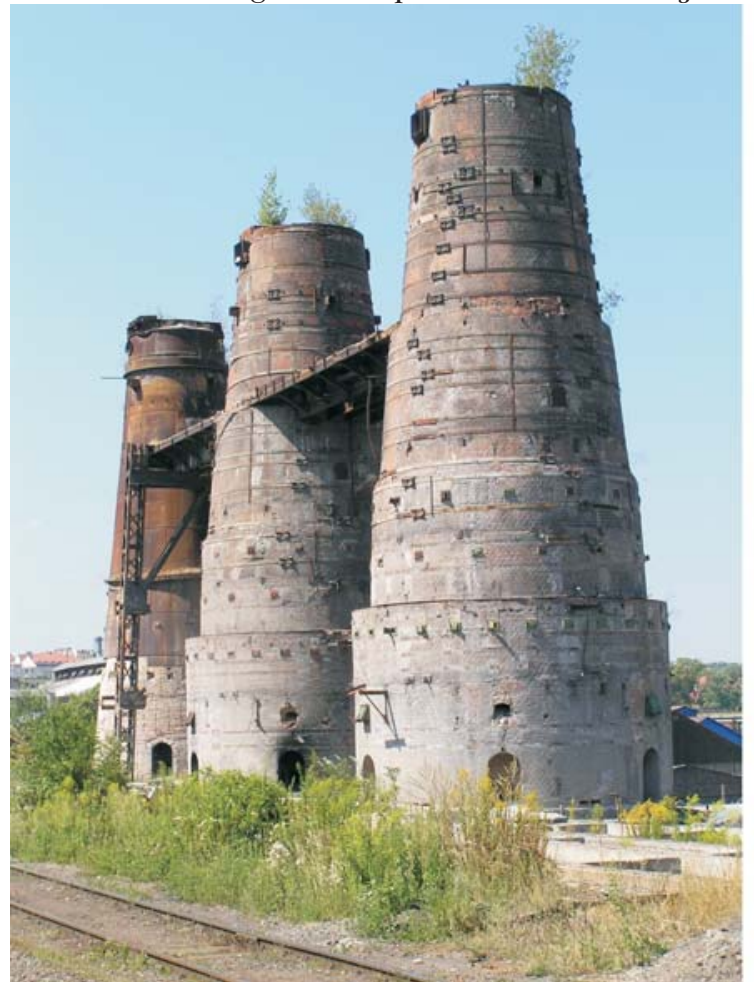

tive and objective levels, and how the perception of them today differs from their contemporary perception. Industrial objects can be viewed as purely technical structures or as works of architecture, but for our kind of evaluation this dichotomy has no importance.

The ways in which industrial and technical structures confront symbolic-aesthetic demands can be divided into five categories:

A Unintended symbols

B Stylistic unity

C Intended metaphors
C. 1 Romantic metaphors
C. 2 Technological metaphors
C. 3 Value of standard
C. 4 The grand total

\section{A Unintended symbols}

The production and technology character of these structures gives them an unmistakable expression and form. They are usually single-purpose objects and freestanding structures, which have acquired almost archetypal significance on account of their typicality and immediateness, and in this sense they also affect the observer's symbolic perception. The form of these objects is defined by their structure and their technical equipment. Some are exceptional examples of an engineering aesthetic.

This category includes limekilns, mining towers, water and windmills, smelting furnaces, cooling towers. These objects have a certain monumentality due to their dimensions and their functional specialization. The outer appearance of these structures already identifies the kind of production involved. (Fig. 1)

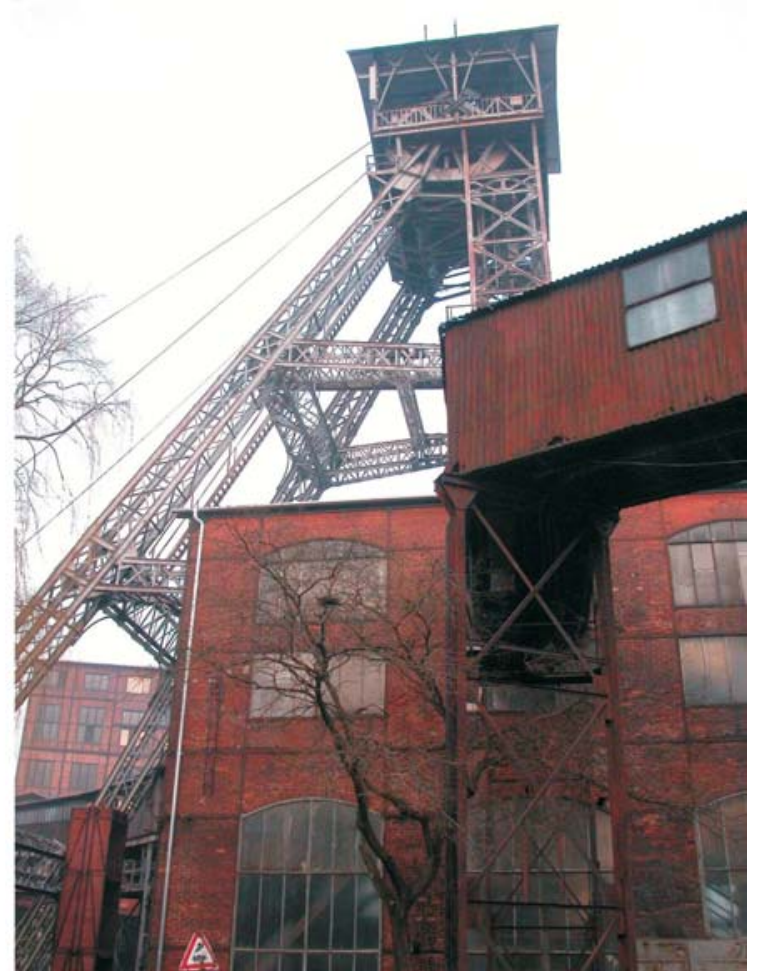

Fig. 1: Category A - unintended symbol. Conical lime-kilns. Former Vojtěch - Koněv Ironworks in Kladno near Prague. Built after 1854 (left). A mining tower of Michal Mine in Ostrava-Michálkovice, 1842. Architect of the redevelopment František Fiala, 1913-1915 (right). 

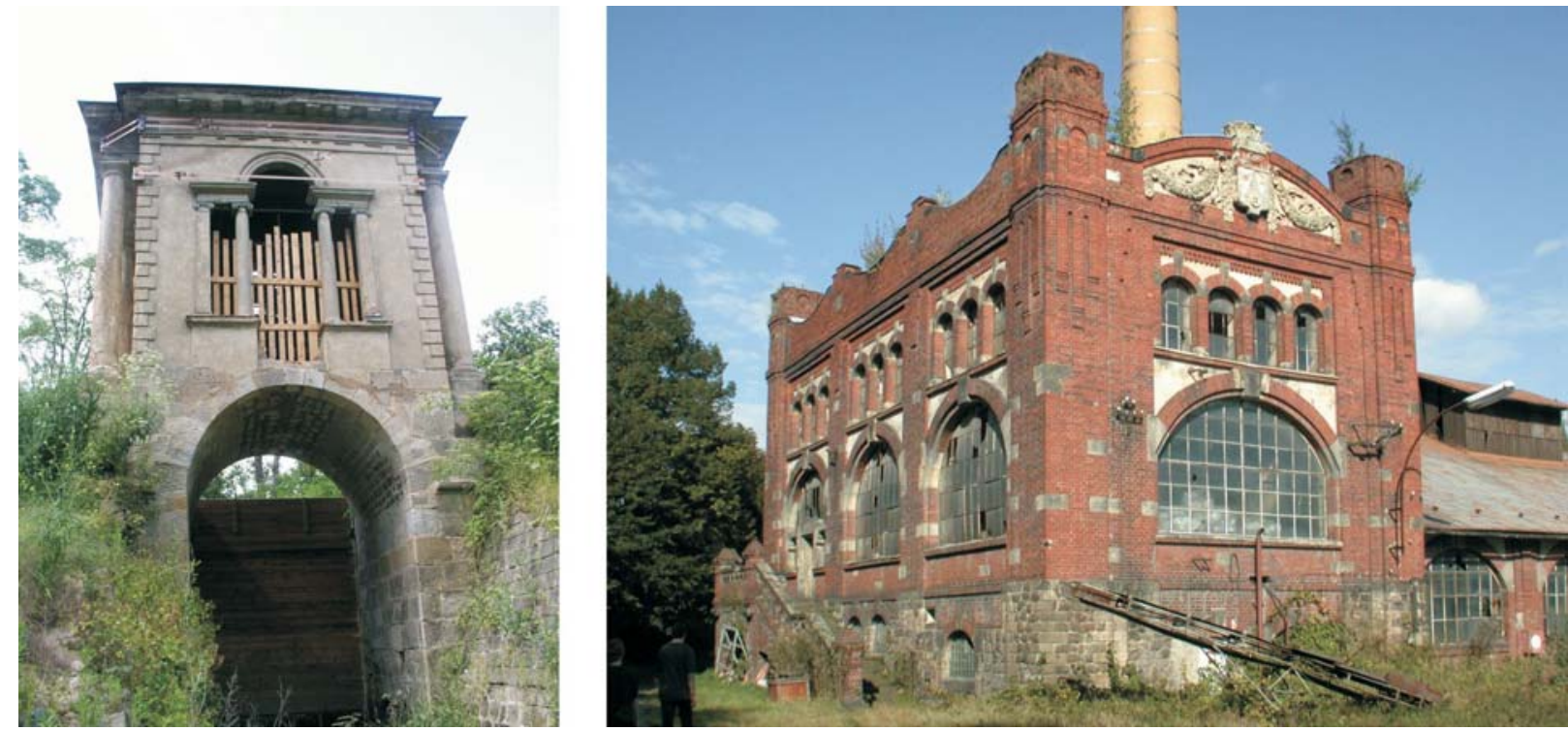

Fig. 2: Category B - stylistic unity. A floodgate. So-called Laudon Pavilion in a Veltrusy palace garden. Built 1792 - 1797 by Matěj Hummel (left). Feigl \& Widrich textile mill (later Textilana, A. G.), Chrastava (Kratzau), built $1904-1907$ by Gustav Sachers and son (right).

\section{B. Stylistic unity}

This category includes objects which have been integrated into the predominant local or historical stylistic and formal framework. In this way the relationship of the structure to the surrounding structures has become harmonised, though at the time of their construction the effort to integrate industrial and technical structures into their surroundings may have been somewhat awkward. These structures can be multifunctional or single-purpose objects.

Rather confusing association are created by the reuse of historical buildings for new production - e.g. in the early stages of industrialisation factories were built inside cloisters, castles, residential buildings. (Fig. 2)

\section{Intended metaphors}

\section{1 Romantic metaphors}

In this case, parts or aspects of traditional architectural styles are used in a new context and are often applied in a very exalted and exotic way. Production buildings in this category are thematically stylised. For example, a paper mill may have been designed like an Egyptian temple (an association with papyrus), or a carpet factory in the style of Islamic architecture (an association with Persian carpets), a tobacco processing plant as a mosque (an association with the exotic origin of tobacco). The appearance of the factory may have served to advertise and promote the goods produced in it. Other typical examples are $19^{\text {th }}$ century pseudo-gothic "industrial castles" or water-towers that resemble minarets or defence architecture. These models borrowed from a glorified version of history, aimed to enhance the significance of the structure. (Fig. 3)

\section{2 Technological metaphors}

The style of the industrial structures may blend with the modern buildings in the area, thus tending to create a formal unity with them. However, due to the specific forms
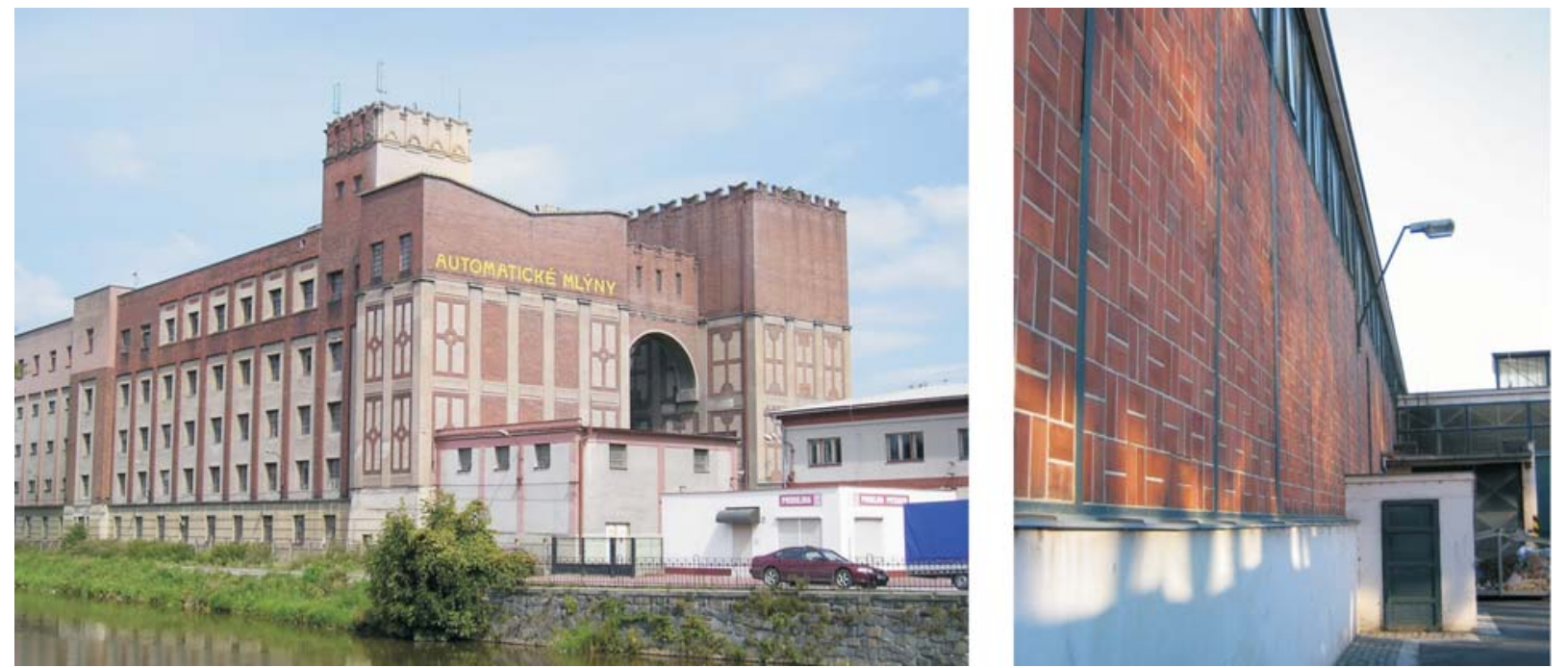

Fig. 3: Category C - intended metaphor (romantic metaphor and metaphor of technology). Winternitz Mill in Pardubice, built 1909-1910 and 1919-1926 by Josef Gočár (left). Ferra a.s. Warehouse in Praha-Holešovice (former L. G. Bondy, a.s.), built 1928-1929 by Josef Kříž (right). 
and accents of production buildings and technical structures they belong rather to the sphere of metaphors. At the present time, in particular built objects metaphorically proclaim technological the sovereignty of technology and production. However, this is very often a general expression only, because in reality their forms are not influenced by the specific kind of technology located inside them. The form sometimes expresses the metaphor of a fully integrated and hidden technology that is totally controlled by man. In fact the control room of a fully automatic bakery can look quite similar to the control room of a nuclear power plant.

In such cases, the most advanced building methods are chosen, even in combination with futuristic stylization. This metaphor symbolises the optimism and the all-powerful potential of the technological era. (Fig. 3)

\section{3 Value of standard}

The value and importance of multifunctional objects lies in their universality, enormous quantity they were built and their long service to industry. Primarily they are interesting engineering feats and structural innovations: e.g. ceiling structures, high capacity ventilation, skylight systems, the use of precast elements and the re-implementation of successful solutions. Secondarily, they can by important for their advanced equipment and machinery, which has probably been replaced several times and may no longer be preserved.

The value of these universal buildings lies in the fact that they form a part of architecture - they have respected the basic sense of proportion and have applied the basic tectonic details and the scheme of the facade is well-balanced. Even their traditional building materials were in harmony with the rest of the city. Their industrial function was manifested by great metal framed windows, chimneystacks, water towers, ramps, cranes, entrance ways and rail tracks. The whole setting of such plants can be seen best form a bird's eye view.

Typical examples of this type of structure are textile mills and engineering works from the 19th century. We can hardly include most of contemporary industrial structures in this category, because they are often built and assembled ad hoc for an immediate functional purpose, without any architectural aim or pretensions. (Fig. 4)

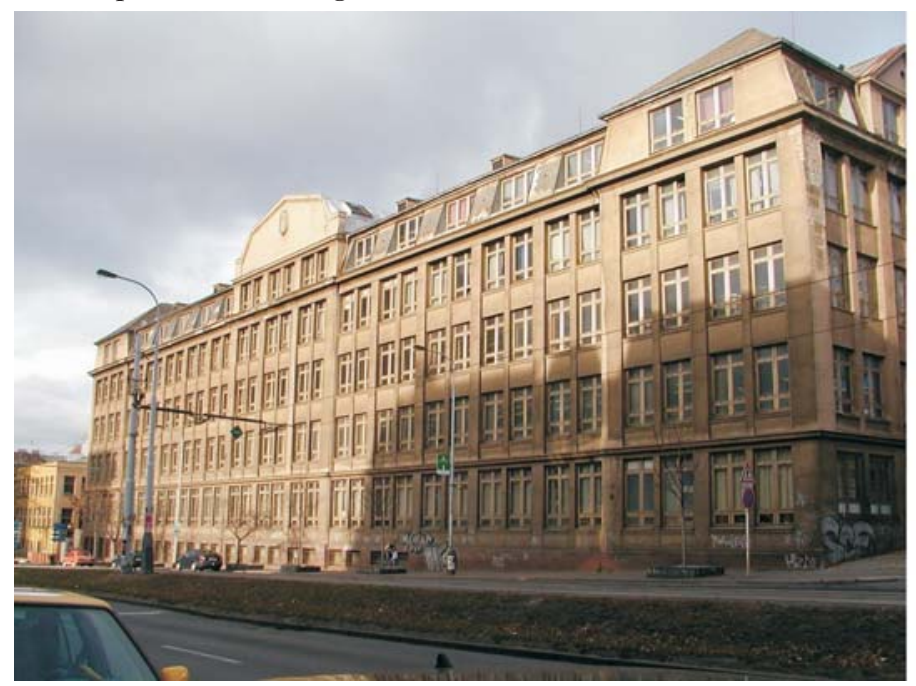

\section{4 The grand total}

Here we are speaking about stylistically and somehow ideologically unified assemblies of buildings and objects. They include not only production buildings but also houses for workers, parks, schools, sports and cultural facilities. This kind of organism emerges as an entity, not unlike the old Utopian falanistera or the urban agglomerations inspired by the garden or industrial conceptions of cities in the $19^{\text {th }}$ century. They were based on capital, economic success, and especially on lofty social ideals with a great deal of optimism. They aspired to create a platform which would renew harmony in human life on all levels.

Architecturally - at least on a small scale and for a period of time such projects achieved a "great unity", similar to that achieved by the great historical styles (in the Czech Republic e.g. Bata's city of Zlín with its satellites).

\section{The Importance of the symbolic-aesthetic criterion in evaluating industrial structures}

In the European context, the heritage of Czech industrial and technical structures is very valuable. This discussion of the topic is a small contribution to promoting a criterion thus far absent, a criterion that would systematically evaluate technical structures from a symbolic-aesthetic perspective. Such an evaluation is an innovation except in the case of some very exceptional works by well-known architects.

Today we admire many industrial structures for their aesthetic appearance, which they acquired from their specific typological class. Paradoxically, however, association with an industrial typology nowadays often underlines the thoughtless destruction of such works. Old technology has been surpassed, and all that remains is the shell of a structure, and its potential aesthetic value is not usually an adequate motive for new investors to make an effort to conserve the building. Moreover, such structures are more complicated to evaluate than other types of buildings, because their urban impact tends to be much broader in scope. When they finish serving their function, it is often necessary to transform much larger

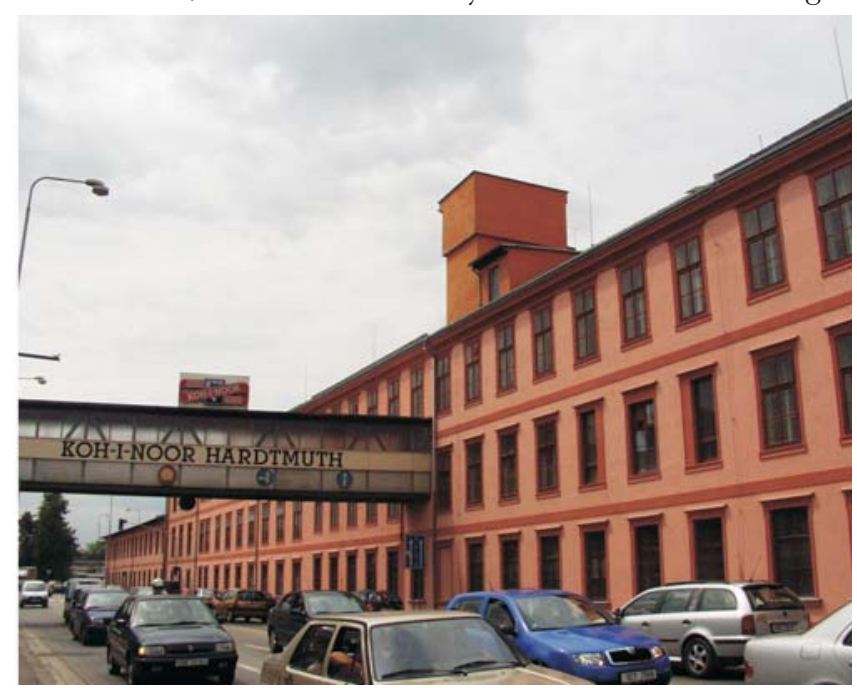

Fig. 4: Category C - value of standard. An engineering works. Koh-i-noor, a.s. (former Waldes and co.) in Praha. Built 1919-1921 by Jindřich Pollert (left). A pencil work KOH-I-NOOR Hardtmuth factory in České Budějovice. Built 1846-1862 and later (right) . 
sections of areas. It also seems that the public, and especially the conservation bodies, have not yet learned to appreciate the quality of these structures. Valuable works are thus disappearing rapidly, without ever having been assessed and without any thought being given to appropriate ways of saving them and converting them for new use in the future.

\section{An analysis of selected technical structures - bridge structures}

Bridge structures have been selected as an example that can quite easily demonstrate the application of the symbolic-aesthetic interpretation of a structural work. Two bridges will be discussed in detail - the Art Nouveau Svatopluk Čech bridge in Prague and the Long Bridge in České Budějovice. Using those examples I will also demonstrate the difference between the traditional and modern forms of bridges.

\subsection{The symbolic perception of water}

In the human mind, water is associated with continuity, the passage of time, the principle of change, and danger. It is also seen as a subconscious source of wisdom. For this reason rivers and water commonly appear in human dreams and myths.

\subsection{Bridges in the organism of the city}

Bridges have always played an important role in the arrangement of the city as a whole. They are important components of the image of the city and its genius loci. The bridges of Prague (especially the most famous Charles Bridge) are an important part of its cityscape, together with many of its towers. Over the ages bridges have also served many secondary functions; for example, they have formed a part of the fortifications, and dwellings, business and shops have been located on them, and they have had representational and leisure functions (e.g. a bridge in Verona, the old London Bridge, Ponte Vecchio, Ponte Rialto, Chinese bridges). These historical structures were always to some extent aesthetically and symbolically cultivated, and were created to form a harmonious part of the city.

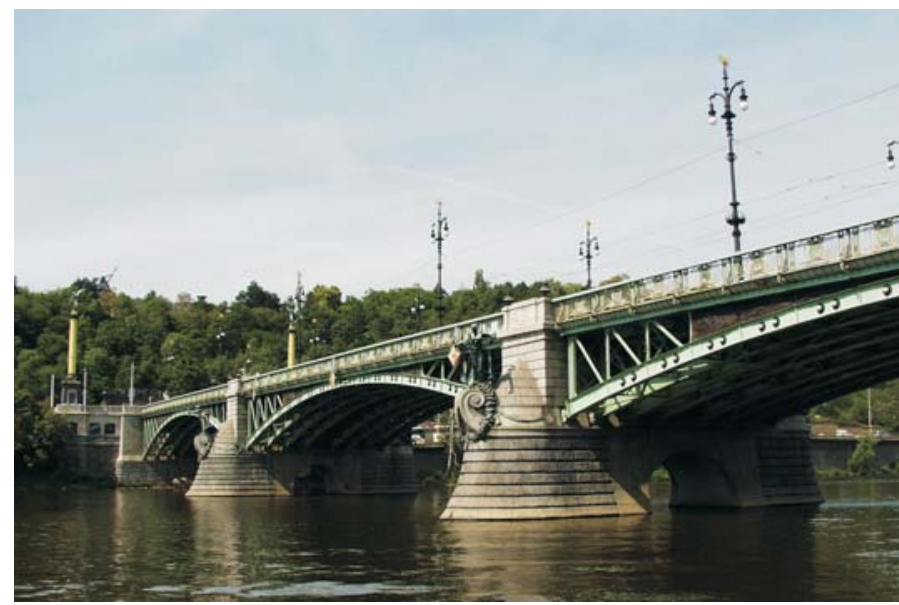

\subsection{Svatopluk Čech Bridge (constructed in 1908-1909, architect J. Koula)}

This Art Nouveau iron bridge is an example of the category of stylistic unity and the romantic metaphor (Figs. 5-9). The bridge consists of three truss arches supported by two concrete pillars cladded with stone. In the fact, the bridge creates a sort of counterpart and at the same time an addition to the famous Charles Bridge. They are comparable on terms of two factors: their technical merit and their artistic merit. At the same time, they represent two different epochs of the national "golden age". From the ideological point of view, Charles Bridge is a manifestation of the universality of the Catholic faith, symbolised by the well-known gallery of open-air statues. On the other hand, the Svatopluk Čech Bridge glorifies the emancipated modern society of the early $20^{\text {th }}$ century.

In an urbanistic context, the Svatopluk Čech Bridge is actually the continuation of a long axis, that starts in the historic market centre, attached to a building of great civic pride - Old Town Hall on the Old Town Square. The axis then runs through the former Jewish Quarter along the new and representative Parizska Street, and then up to the bridge (Fig. 7). This straight axis was intended to continue through the triumphal arch above the planned opening in the steep Letna hill (Fig. 5). The culmination and planned conclusion of this line was to be a new city quarter, in which government buildings would be centred. In this way the bridge can be compared to Charles Bridge, which formed an integral part of the Royal Route that ran through the complicated organism of the medieval city. The route symbolically unified the objects of spiritual power with their temporal counterparts. At one end of the route is the royal palace, with the cathedral as a sacred source of authority and power. The reverse view presents the city as an image of blessed human activity. Here, one direction complements the opposite directions - the design represents the way of salvation as a two-way street. The Svatopluk Čech Bridge also created a specific vista of the new centre of gravity - the government buildings - in accordance with the modern belief that all power comes from the people, not from God.

As regards form, we have already said that the Art Nouveau Svatopluk Čech Bridge is the continuation of the trium-

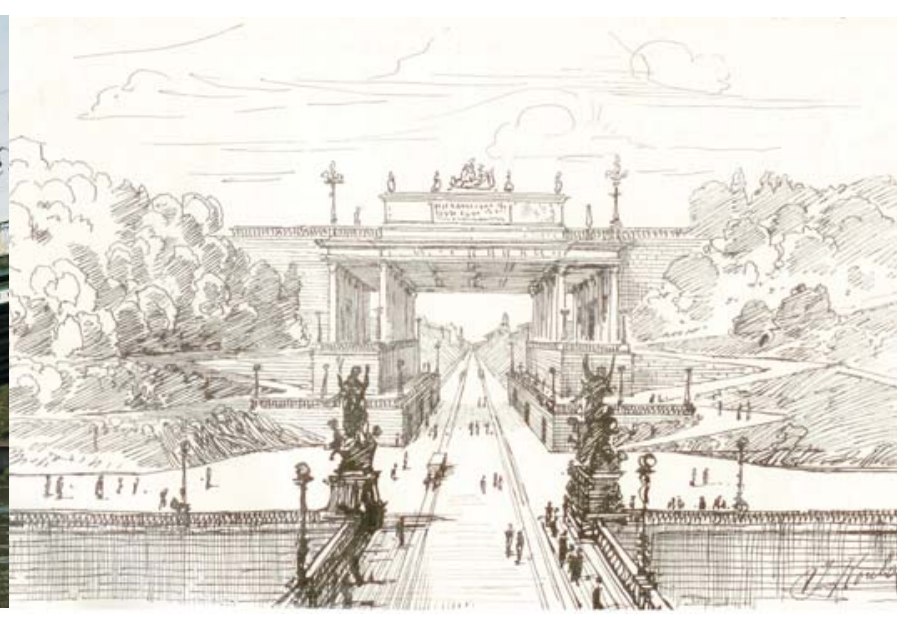

Fig. 5: Svatopluk Čech Bridge in Prague. Built 1908-1909 by J. Koula. The face side of the bridge (left). The design of the triumph arch at the Letná hill by J. Koula, 1897 (right). 

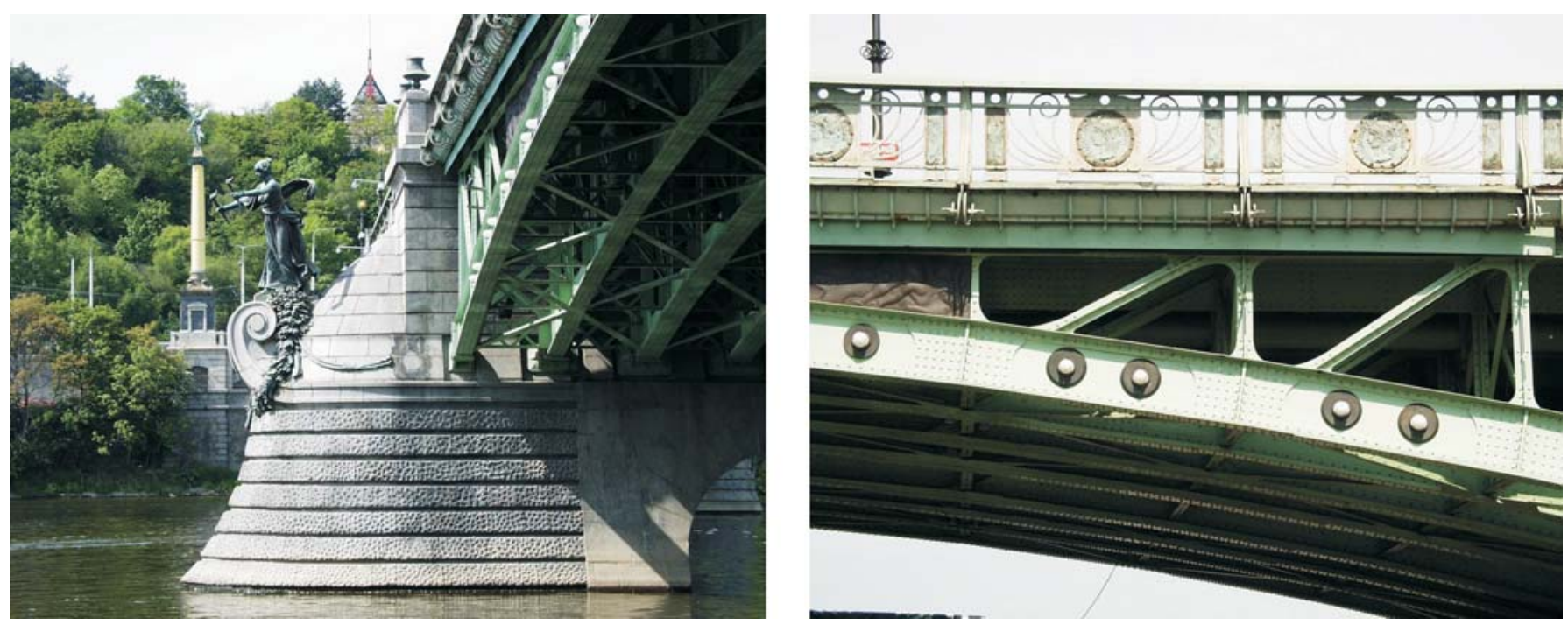

Fig. 6: Svatopluk Čech Bridge in Prague. Built 1908-1909 by J. Koula. The face side of the bridge with an female figure holding a torch (left). The railing with identical medallions with female face, "chain" of electric lamps and relief sculptures (right).

phalism of Parizska Street (Fig. 7). Stylistically, it is a mixture of all historical styles, but without religious accents. In a spiritual sense, the artists and architects preferred pre-Christian motives. The whole project is a manifestation of the optimism and ambition of the era of prosperity, based on modern management, modern technology and a modern social system.

The decoration of the bridge is organised on three main levels (Figs. 5, 6). The lowest level is thematically related to water. The mid-level is dedicated to man and to work associated with water. The upper level belongs to protective forces and beings. In this way all the strategic points and levels of the bridge are symbolically occupied.

The face of the Svatopluk Čech Bridge is the upstream side (Fig. 7). Surprisingly, the coats-of-arms of Prague are on the opposite side, on the rear of the structure, like as is flag of the nation, which is situated on the stern of a ship. Here, the flag is protected by the whole mass of the ship. In our case, this supreme symbol is flanked by a pair of water dragons, hydras that only the divine Hercules was able to overcome.
Here, these creatures are placed in the role of loyal monsters as guard dogs of a sort. This kind of application recalls lion's heads that have to hold iron rings in their mouths, or frightening cathedral gargoyles that facilitate roof drainage. Below the coats-of-arms we also see the face of the water God, captured in the wall. He, too, guard the bridge, watching over everything closely, and perhaps shouting through his open mouth.

On the face side of the bridge there are two prominent female figures holding a torch in their hands (Fig. 6). They may also be symbols of republican liberty, like the Statue of Liberty in New York. The torches used to have gas lamps on them, lighting the waterway, ceaselessly welcoming the river and the approaching boats. In the night, they warned of the potentially dangerous presence of two pillars. These gigantic ladies stand on pillars formed in the shape of decorative ship bows festooned with flowers.

The spaces between the arches are decorated with relief sculptures of naked bodies of real and mythical creatures,
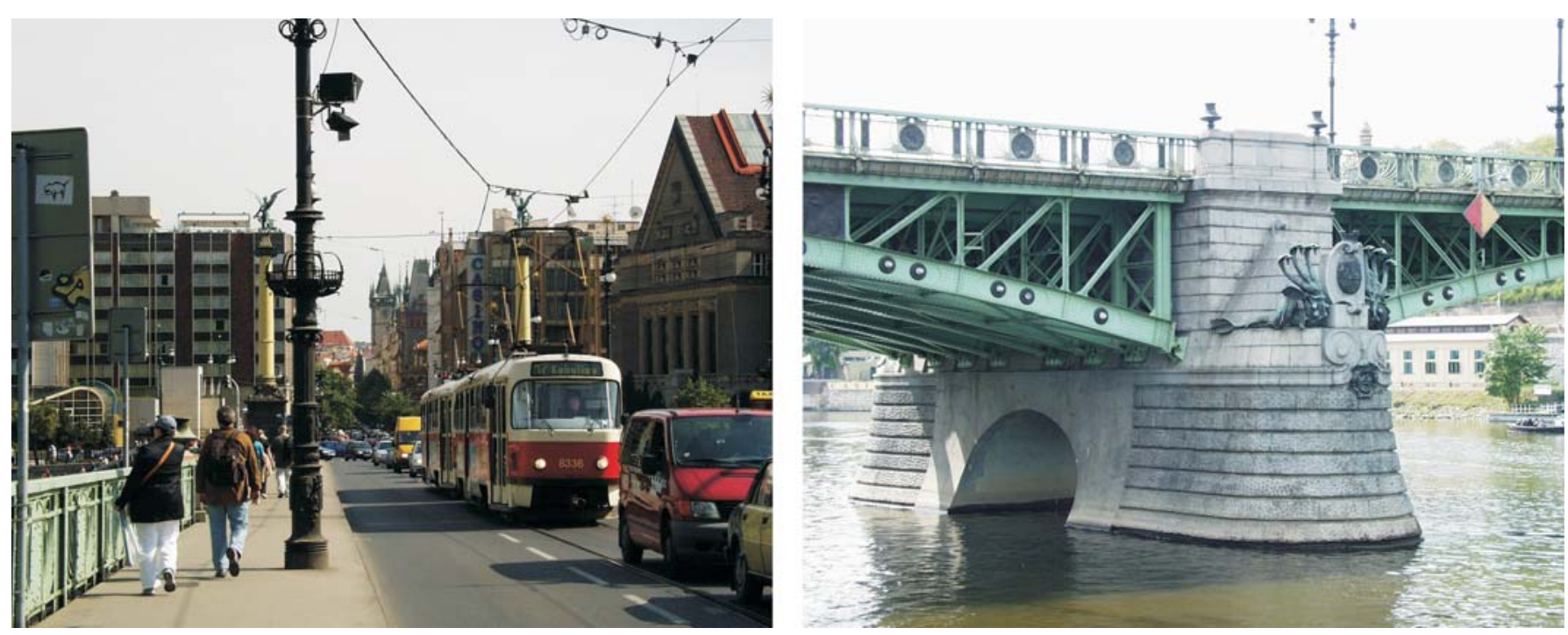

Fig. 7: Svatopluk Čech Bridge in Prague. Built 1908-1909 by J. Koula. A specific vista to Pařížská Street (left). The upstream side of the bridge with coats-of-arms of Prague and water dragons (right). 

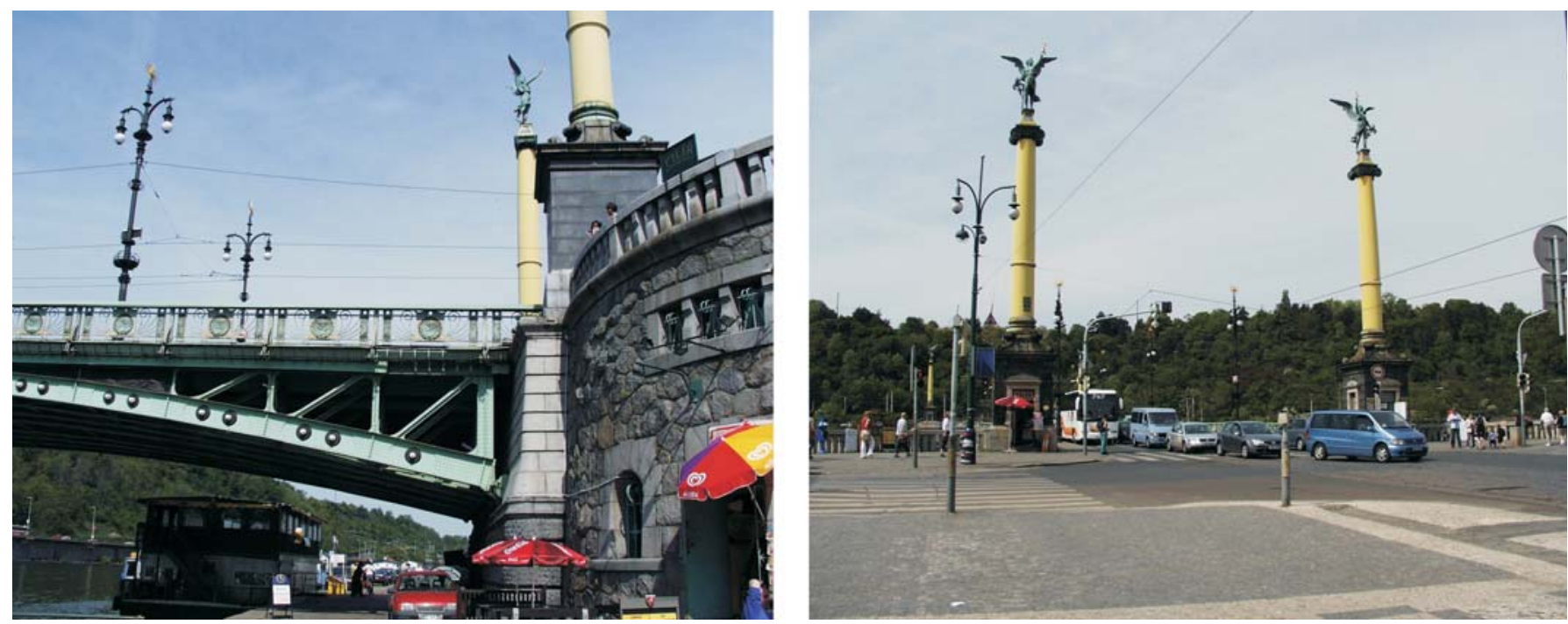

Fig. 8: Svatopluk Čech Bridge in Prague. Built 1908-1909 by J. Koula. Decoration of the spaces between the arches, candelabras and small stone houses on the treshold of the bridge (left). The threshold of Svatopluk Čech bridge with seven-meter-high columns.

which play together in harmony. The guidelines of the arches are marked by a chain of electric lamps that look like grand pearls, supernaturally taken from the depths of the purifying water, as in a Wagnerian opera (Figs. 6, 8).

On the terrain level of the bridge there are motifs based on work related to water. In the centre of the railing panels there are identical medallions with a beautiful female face and the Latin inscription: Prague, mother of cities (Figs. 6, 8). The replication of this image and the inscription are like a sort of mantra, proclaiming the eternity of the city. Even the mandala-like shape of the relief sculptures refers to the world of universal archetypes. On the top of the railing, above the pillars there are pairs of urns that borrow their shape from

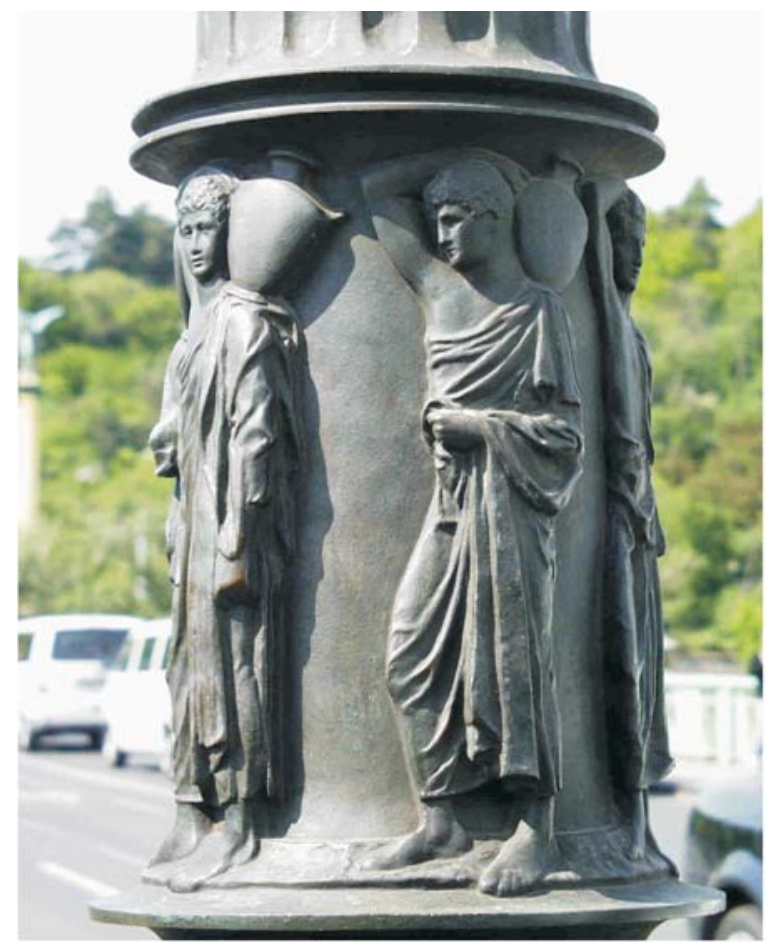

ancient times and remind us of the process of death and rebirth from earth and water - a natural cycle (Fig. 7).

The tower gates at Charles Bridge are of a defensive character. On the threshold of Svatopluk Čech Bridge, by contrast, all that can be found are some small stone houses crowned by seven-meter-high columns (Fig. 8). These lean and structures, placed at a good distance from each other, are inviting to free and rapid movement, rather than creating an obstacle. They form as it were open gates indicating just the symbolic beginning and end of the bridge. At the top of the columns there are small glass structures, and above them stand four poetic figures of Victory. At night they stand on the light of shining lanterns. In this connection we can recall the old Christian

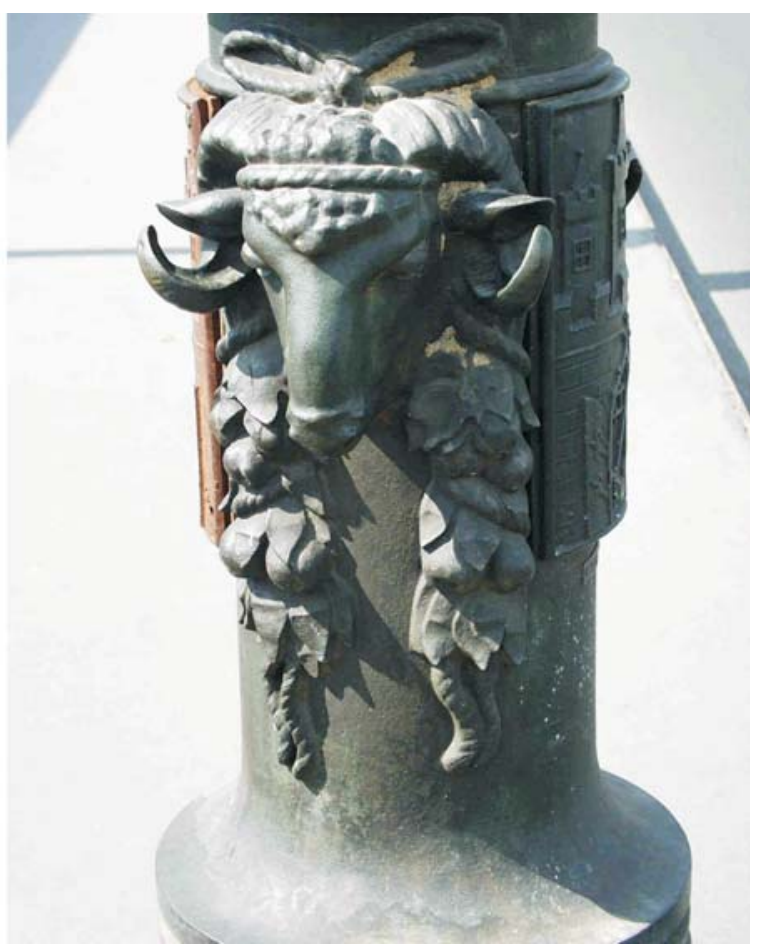

Fig. 9: Svatopluk Čech Bridge in Prague. Built 1908-1909 by J. Koula. The decoration of candelabras - relief works depicting water-related trades (left), a head of a ram (right). 

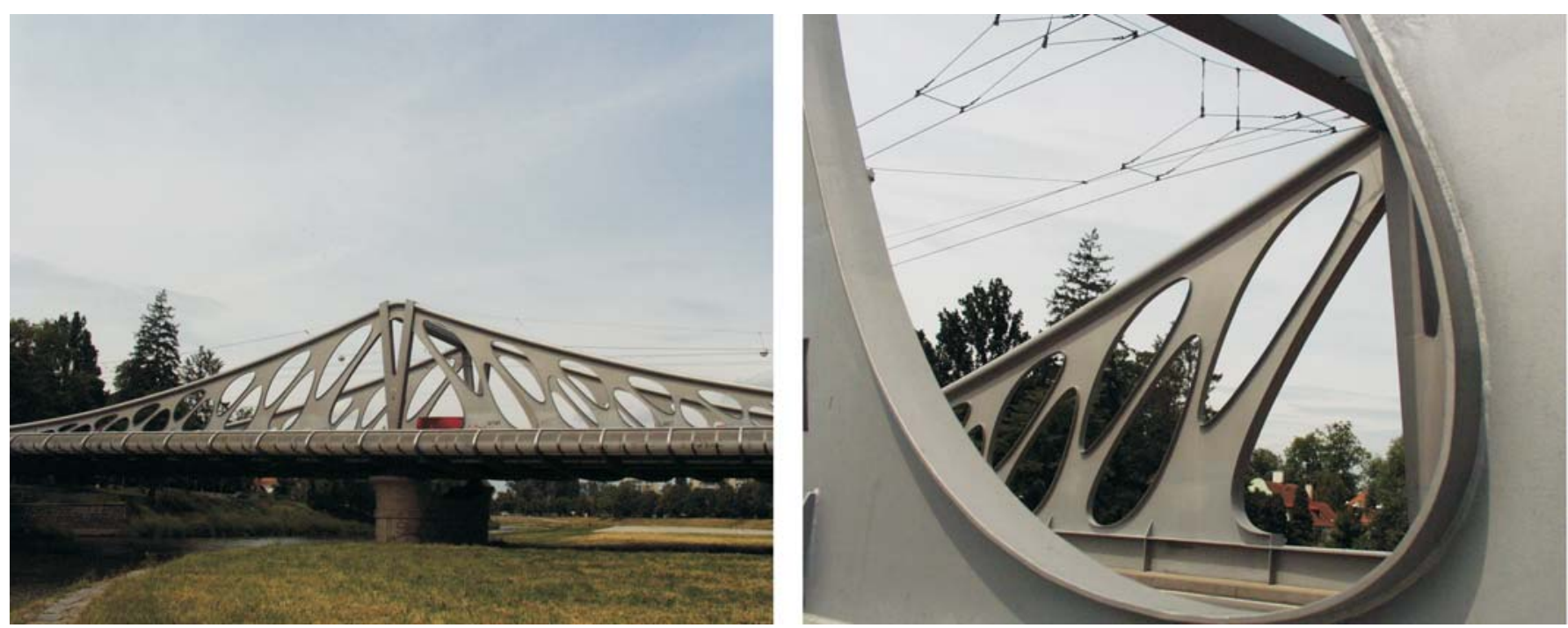

Fig. 10: Long Bridge in České Budějovice. Built 1999 by Roman Koucký and Tomáš Rotter. The structure of the bridge (left). The rubber-like deformed openings of the side beams (right). (Authors of figures: Lenka Popelová and the database of the VCPD, CTU in Prague.)

image of the Virgin Mary standing on the crescent, or the Lady dressed in the Sun. According to a more ancient vision the image is reminiscent of the Goddess Nike holding the branch of victory.

Other impressive vertical features are the candelabras (Figs. 7, 8, 9), the lower parts of which are decorated with relief work. These originally depicted several water-related trades, such as rafters and fishermen. These have today been replaced by replicas of one of the originals, which depicts people carrying jugs of water on their shoulders (Fig. 9). The figures have an air of peace and dignity to them, like the figures from the Ara Pacis altar in Rome. The same place is marked by an almost three-dimensional image of the head of a ram (Fig. 9). This seems to symbolise the nature of the power of man and according to the ancient models perhaps the sacred sacrifice - in this case through dedicated human work. Slightly higher up, there are metal platforms for flowers, which used to decorate the whole structure on holidays and festivals.

At the highest point of the candelabras there are gilded images of another life-giving element - the disk of the Sun with rays of sunshine. Its simplicity recalls the monstrances carried by the Hussites in front of their troops. At night, this image is simulated by two hanging electric lamps.

In summary, the symbolic meaning of this bridge is the celebration of elements of nature, human work and the new social perspective. On the other hand, Charles Bridge is guarded by the images of saints, including some Czech compatriots, who together help us to pass safely across to the opposite shore, "the other side", and they remind us that this walk is certainly not endless.

\subsection{Modern bridges}

The metaphor of modern bridges is often indifferent to their surroundings and to the genius loci of the whole city. Such bridges create the impression that the problems to be solved and the particular situation of the place are often artifi- cially complicated to create an ambitious challenge. In addition to their radical technical designs and forms, new bridges are also stylised to be contemporary. This additional articulation can be much stronger than the plain structural design. Because of its extremity, such an approach can disturb the genius loci of the surroundings.

\subsection{Long Bridge in České Budějovice (constructed in 1999, arch. R. Koucký, T. Rotter)}

This bridge is an example of the metaphor of technology category, due to its simple functional structures with typical production and technical features (Fig. 10). The steel structure of this cable-stayed bridge is supported by one pillar. Its typical silhouette resembles the old chain bridges. However, because of the expected loads and the small span of the river, this structure seems to be unnecessary.

Hanging cables are attached in the centre of the bridge on a two-part frame. In the place of the anchorage, this frame simulates the separation of the parts, and simulates the pull and the weight of the load. The illusion of deformation also has an aesthetic function in other parts of the bridge. We see the rubber-like deformed openings in the steel sheets, which are part of the side beams (Fig. 10). These openings resemble the holes that form the inner structure of aircraft. The metallic character and the round shape enhance this association. The radically outward arched railing also has something in common with the leading edge of the giant wing of an airplane. Despite the technoid character of the bridge, however, the general impression has something surprisingly akin to the style of Art Nouveau.

The bridge is located close to some traditional houses and it is not far from the historical centre of the city. From this point of view, the aircraft metaphor is rather improper. This new bridge blocks off its surroundings and draws all attention to itself, a feature that has also been criticised by other architects and experts. 


\section{Conclusion}

This paper is a contribution in support of a criterion that will systematically evaluate industrial structures, including bridge structures, from a symbolic-aesthetic perspective. This approach should serve as a useful argument in efforts aimed at conserving and regenerating such structures.

\section{Acknowledgments}

This research was supported by IG CTU0622115 Aesthetic and Symbolic Dimension of Industrial Buildings. One of the Classification Categories in 2006 and by RP MŠMT 61-66100 Interdisciplinary Perspectives on the Development of Technical Fields and Industrial Architecture in the Czech Republic and the Creation of a Typology in 2006.

\section{References}

[1] Bradley, B. H.: The Works. The Industrial Architecture of the United States. New York, Oxford University Press, 1999.

[2] Čenský, A.: Návrh na úpravy Letenské pláně dle prof. J. Kouly. Architektonický obzor. Vol. VI (1907), p. 31-32, 34-35, 37-38, 41-42.

[3] Čenský, A.: O původním návrhu arch. prof. Kouly na komunikaci letenským průkopem. Architektonicky obzor, Vol. IX (1910), p. 13, 15-17.

[4] Darley, G.: Factory. London, Reaktion Books Ltd., 2003.

[5] Fischer, J., Fischer, O.: Pražské mosty. Praha, Academia, 1985.
[6] Föhl, A.: Bauten der Industrie und Technik. Baden, Schriftenreihe des Deutschen Nationalkomitees für Denkmalschutz.

[7] Hozák, J.: Krása průmyslové architektury. Industriální architektura - nevyužité dědictví. (Editors: Fragner, B., Hlaváček, E.), Praha, NTM v Praze, OA, ČFVU 1990, p. 10-13.

[8] Jung, C. G.: Duše moderního člověka. Brno, Atlantis, 1994.

[9] Kučera, V.: Architektura mosti̊. Praha, Vydavatelství ČVUT v Praze, 2002.

[10] Koula, J.: Návrh vstupu komunikace letenské od arch. Prof. J. Kouly. Architektonický obzor, Vol. IX (1910), p. 19-21.

[11] Neaverson, P., Palmer, M.: Industrial Archeology. London and New York, Routledge, 2000.

[12] Šeneberger, T.: Rekonstrukce výrobně-technických staveb k novým účeliom. Praha, NTM v Praze, 1995.

[13] Urlich, P.: Klasický a abstraktni model v architektuře 20. století. Praha, Vydavatelství ČVUT v Praze, 1992.

Ing. arch. Lenka Popelová

phone: +420224355322

email: lenka.popelova@fsv.cvut.cz; lenpop@centrum.cz

Department of Architecture

Czech Technical University in Prague

Faculty of Civil Engineering

Thákurova 7

16629 Prague 6, Czech Republic 